\title{
SPIN-PÁLYA KORREKCIÓK A KOMPAKT KETTŐS RENDSZEREK MOZGÁSÁNAK LEÍRÁSÁBAN II. - A SZÖGMENNYISÉGEK MOZGÁSEGYENLETEI
}

\author{
Majár János \\ egyetemi docens, Miskolci Egyetem, Fizikai és Elektrotechnikai Intézet, Fizikai Tanszék \\ 3515 Miskolc, Miskolc-Egyetemváros, e-mail: fizmajar@uni-miskolc.hu
}

\begin{abstract}
Absztrakt
A gravitációs hullámok első közvetlen detektálása után a kihivás az, hogy a detektorok segitségével minél pontosabb képet kapjunk az ezen hullámokon keresztül megfigyelhetö jelenségekröl, vagyis megszülessen a gravitációshullám-csillagászat. Ebben kiemelt szerepe van a kompakt objektumok által alkotott kettös rendszereknek, mivel az általuk kibocsátott hullámok széles paramétertartományban nagy pontossággal leirhatók. Ehhez azonban szükségünk van a kettös rendszer mozgásának leírására. Ezt a poszt-newtoni sorfejtés alkalmazásával tesszük meg, figyelembe véve a pálya excentricitásának és a testek forgásának hatásait. A korábbi munkák tisztázzák a szeparációs vektor nagysága változásának részleteit, azonban a kibocsátott gravitációs hullámok leírásához szükségünk van a vektorirányokat jellemzö szögmennyiségek dinamikájának leírására is. Az ehhez szükséges egyenletek kerülnek jelen cikkben származtatásra, illetve részletezésre kerül ezek megoldásának módszerei. Célkitüzés továbbá a korábbi, alapanyagként használt publikációk hibáinak feltárása, javitása.
\end{abstract}

Kulcsszavak: általános relativitáselmélet, gravitációs hullámok, kompakt kettös rendszerek, posztnewtoni sorfejtés, Euler-szögek

\begin{abstract}
After the first direct detection of gravitational waves, the challenge is to get the most exact picture possible of the phenomena that can be observed using these waves, i.e. to realize the birth of gravitational wave astronomy. The binary systems formed by compact objects have a special role in this, since the waveforms emitted by them can be described with high accuracy over a wide range of parameters. In order to derive these waveforms, however, one needs to describe the motion of the binary system. We do this by using the post-Newtonian series expansion, taking into account the effects of the eccentricity of the orbit and the rotation of the objects. Earlier works have clarified the details of the changes of the length of the separation vector; however, to describe the emitted gravitational waves we need to describe the dynamics of the angular variables that characterize the vector orientations. In this paper the necessary equations are derived, and the methods to solve them are also described. The aim is also to explore and correct the errors of previous publications that we used as starting material.
\end{abstract}

Keywords: general relativity, gravitational waves, compact binary system, post-Newtonian series expansion, Euler angles 


\section{Bevezetés}

Az amerikai LIGO detektorrendszerben 2015-ben megtörtént a több évtizedes munkának köszönhető áttörés, közvetlenül detektálták az első gravitációs hullámot [1]. Újabban több, hasonló mérési eredmény is született, amelyekbe a Virgo detektorrendszer is bekapcsolódott, illetve az első kettős neutroncsillag esetén az elektromágneses jelét is érzékelték az összeolvadási folyamatnak [2-5].

Ezzel újabb igazolást nyert az Általános Relativitáselmélet, de ezen felül új ablak is nyílt a világegyetemre, hiszen olyan asztrofizikai folyamatokat is megfigyelhetünk a gravitációs hullámoknak köszönhetően, amelyeket az elektromágneses sugárzáson alapuló mérések egyikével sem. Ehhez az első detektálás után most ki kell fejlesztenünk azokat az elméleti és kísérleti eszközöket, amelyek segítségével a vizsgált hullámforrások fizikai paramétereit is mérni tudjuk.

A neutroncsillagok és fekete lyukak alkotta kettős rendszerek (röviden kompakt kettősök) ebben nagy segítségünkre vannak, mivel ezek hullámformái nagy pontossággal leírhatók. Ezt több, különböző módszerrel érhetjük el a kettős rendszer életciklusának egyes szakaszaiban. Az úgynevezett közeledési szakaszban az egyik meghatározó módszer a poszt-newtoni közelítés $[6,7,8]$. Ebben a közelítésben az objektumok $v$ sebességét, a sürüséghez viszonyított feszültségtenzort és a $G M / a c^{2}$ gravitációs potenciált (ahol $M$ a forrás tömege, $a$ a forrás jellemző kiterjedése, $G$ pedig a gravitációs állandó) kis paramétereknek tekintjük, és ezek maximumát tekintjük a poszt-newtoni sorfejtés $\varepsilon$ paraméterének, amely szerint az egyes fizikai mennyiségeket sorba fejtjük.

Ezt az eljárást alkalmazva a hullámformák származtatásának első lépése a kettős rendszer mozgásának minél általánosabb leírása. Ennek eredményeit helyettesítjük be a hullámforma-kifejezésekbe, így kapva meg a konkrét forrás által kibocsátott, és a detektor által érzékelhető jelalakot. Ezért ezen cikk-sorozatban a kettős rendszer dinamikájának poszt-newtoni leírásával foglalkozunk.

Bár a gravitációs sugárzás hatására a pálya excentricitása csökken, mi igyekszünk azt minél általánosabban figyelembe venni, mivel bizonyítható, hogy a lehetséges jelforrások nem elhanyagolható hányadánál a kettős rendszer pályája még az összeolvadás előtti pillanatokban sem tekinthető körpályának.

A sorfejtésben a perturbálatlan (,newtoni”) mennyiségeket $\mathrm{N}$ alsó index-szel jelöljük, a posztnewtoni korrekciókat pedig a rendjük (pl. 1PN az elsőrendủ korrekcióknál) alsó index-ben történő szerepeltetésével. Ezen felül figyelembe vesszük, és a formalizmusba bevezetjük a kompakt objektumok forgásából származó korrekciókat is. Ennek feltétele, hogy a spin-vektorok nagyságára teljesüljön, hogy $S_{i} / L_{N} \sim \varepsilon^{0,5}$, ahol $L_{N}$ a newtoni (perturbálatlan) impulzus-momentum vektor nagysága.

Ennek köszönhetően a mozgás leírásában a spin-pálya kölcsönhatás 1,5PN rendben jelenik meg (a spin-pálya kölcsönhatás korrekcióit SO index-szel jelöljük), a spinek közötti spin-spin kölcsönhatás 2PN rendü, ahogy a kvadrupól-monopól kölcsönhatás korrekciói is.

Mivel a spin-pálya kölcsönhatás legalacsonyabb rendben 1,5PN rendü korrekcióként jelenik meg a kettős rendszer mozgásának leírásában, cikkeinkben a fö célkitüzés a mozgás leírása 1,5PN rendig, figyelembe véve a pálya excentricitásának és a kompakt objektumok forgásának hatásait.

Fontos még kiemelni, hogy bár jelen cikkekben ezzel nem foglalkozunk, a gravitációs sugárzás visszahatása a mozgásra 2,5PN rendben jelenik meg. Ennek során változnak a mozgás meghatározó mennyiségei (energia, impulzus-momentum, stb.), és ennek hatására a kibocsátott gravitációs hullámok amplitúdója és frekvenciája is növekszik, létrehozva a kettős rendszerek összeolvadására jellemzö „chirp” jelalakot.

A továbbiakban az egyszerüség kedvéért a $c=G=1$ mértékegységrendszert alkalmazzuk. 


\subsection{A mozgás leírását meghatározandó mennyiségek}

Az általunk vizsgált gravitációs hullámforrások olyan kettős rendszerek, amelyekben az egyes kompakt objektumok tömege $m_{1}$ és $m_{2}$, forgásukat pedig az $\vec{S}_{1}$ és $\vec{S}_{2}$ spin-vektorokkal jellemezzük. Ezen kettős rendszerek dinamikájának leírásához szükségünk van az $\vec{r}$ szeparációs vektor (a két objektumot összekötő vektor), a $\vec{v}$-vel jelölt relatív sebességvektor, illetve az egyes testek forgását leíró $\vec{S}_{i}$ spin-vektorok komponenseinek kiszámítására.

A mozgásegyenlet származtatása során szükségünk lesz a különböző impulzus-momentum menynyiségekre. A gravitációs hullámok leírásában kritikus fontosságú a pálya-impulzusmomentum vektora, ami az $\vec{L}_{N}=\mu \vec{r} \times \vec{v}$ összefüggéssel definiálható. Az összefüggésben szereplő $\mu$ jelöli az úgynevezett redukált tömeget, amely $\mu=m_{1} m_{2} / m$, ahol $m$ a rendszer teljes tömege, vagyis $m=m_{1}+m_{2}$. A másik fontos impulzus-momentum vektor a $\vec{J}$ teljes impulzus-momentum, amely a 2,5PN sugárzási rendig mozgásállandó:

$$
\vec{J}=\vec{L}_{N}+\vec{L}_{1 P N}+\vec{L}_{S O}+\vec{S}
$$

ahol a különböző poszt-newtoni korrekciók

$$
\vec{L}_{1 P N}=\vec{L}_{N}\left[\frac{1-3 \eta}{2} v^{2}+(3+\eta) \frac{m}{r}\right], \quad \vec{L}_{S O}=\frac{\mu}{r^{3}} \vec{r} \times[\vec{r} \times(2 \vec{S}+\vec{\sigma})]-\frac{\eta}{2}[\vec{v} \times(\vec{v} \times \vec{\sigma})],
$$

és ahol $\eta=\mu / m$, illetve használjuk az $\vec{S}=\vec{S}_{1}+\vec{S}_{2}$ teljes spin vektor és a $\vec{\sigma}=\varsigma_{1} \vec{S}_{1}+\varsigma_{2} \vec{S}_{2}$ tömeggel súlyozott spinvektor $\left(\varsigma_{1}=m_{2} / m_{1}, \varsigma_{2}=m_{1} / m_{2}\right)$ rövid jelöléseket. Kiemelendö, hogy a spinvektorok bevezetésénél az úgynevezett kovariáns SSC (spin supplementary condition) feltételt választjuk, ami meghatározza a dinamikai mennyiségek alakját $[9,10]$.

Ezen vektorok konkrét kiszámolásának alapja a kettős rendszer Lagrange-függvényéből származtatott gyorsulásvektor.

$$
\begin{gathered}
\vec{a}=\vec{a}_{N}+\vec{a}_{1 P N}+\vec{a}_{S O}, \text { ahol } \vec{a}_{N}=-\frac{m}{r^{3}} \vec{r}, \\
\vec{a}_{1 P N}=\frac{m}{r^{3}}\left\{\left[(1+3 \eta) v^{2}-2(2+\eta) \frac{m}{r}-\frac{3}{2} \eta \dot{r}^{2}\right] \vec{r}-2(2-\eta) \dot{r} r \vec{v}\right\}, \\
\vec{a}_{S O}=\frac{1}{r^{5}}\left\{6(\vec{r} \times \vec{v}) \cdot(\vec{S}+\vec{\sigma}) \vec{r}-r^{2} \vec{v} \times(4 \vec{S}+3 \vec{\sigma})+3 \dot{r} r[\vec{r} \times(2 \vec{S}+\vec{\sigma})]\right\} .
\end{gathered}
$$

A gravitációs hullámok leírása során ezeken túl szükségünk van még a $\vec{N}, \vec{p}, \vec{q}$ vektor-triád kifejezéseire. Ezek őrzik a detektor és a kettős rendszer pályasíkjának egymáshoz képesti orientációjának információit, ezekre a mennyiségekre van szükségünk, hogy az általánosabb $h_{T T}^{i j}(t)$ tenzorból (ez írja le a téridő-perturbációkat a transzverzális spúrtalan - TT - mértékben) projektálni tudjuk a $h_{+}(t)$ és $h_{\times}(t)$ polarizációs állapotokat 


$$
h_{+}(t)=\frac{1}{2}\left(p_{i} p_{j}-q_{i} q_{j}\right) h_{T T}^{i j}(t), \quad h_{\times}(t)=\frac{1}{2}\left(p_{i} q_{j}+q_{i} p_{j}\right) h_{T T}^{i j}(t),
$$

amelyek megadják a detektorban érzékelhető jelalakot

$$
h(t)=F_{+} h_{+}(t)+F_{\times} h_{\times}(t),
$$

ahol az $F_{+}$és $F_{\times}$függvények konkrét alakját a detektor geometriája adja meg.

A számítások elvégzéséhez két koordináta-rendszert vezetünk be. Az első az úgynevezett invariáns koordinátarendszer, amelyet a teljes impulzus-momentumhoz rögzítünk, $\vec{J}$ iránya adja meg a 'z' tengely irányát. Ebben a koordinátarendszerben végezzük majd el a deriválásokat és integrálásokat. Az ebben a koordinátarendszerben felírt vektorokat alsó index-be írt 'inv' jelöléssel látjuk el.

Ezen túl bevezetjük az együtt-mozgó koordinátarendszert, amelyben $\vec{L}_{N}$ jelöli ki a 'z' irányt, az 'x' koordináta-tengely irányát pedig az $\vec{r}$ szeparációs vektorhoz rögzítjük. Ebben a koordinátarendszerben végezzük majd el a gravitációs hullámok polarizációs állapotainak projektálását. Továbbá, mivel ez természetesen igazodik a mozgáshoz, a dinamikára vonatkozó eredményeinket ebben a koordinátarendszerben érdemes ellenőriznünk és értelmeznünk. Az ebben a koordinátarendszerben felírt vektorok alsó index-be írt jelölése ' $c o$ '.

A mozgást meghatározó szeparációs vektor komponenseit Euler-szögekkel írjuk fel. Ezekkel a szeparációs vektor alakja az invariáns rendszerben az alábbi:

$$
\vec{r}_{i n v}=r\left(\begin{array}{c}
\cos \phi \cos \psi-\cos \imath \sin \phi \sin \psi \\
\sin \phi \cos \psi+\cos \imath \cos \phi \sin \psi \\
\sin \imath \sin \psi
\end{array}\right),
$$

ahol $\iota$ a $\vec{J}$ és $\vec{L}_{N}$ vektorok által bezárt szög, $\phi$ írja le a pálya-precessziót (vagyis a pályasík és a $\vec{J}$-re merőleges sík metszetének egy adott referencia-irányhoz mért szögét), és $\psi$ adja meg le a szeparációs vektor irányát a pályasíkon. Ezekkel bármely vektor esetén egyszerü forgásmátrixokkal megadhatjuk a transzformációt az együtt-mozgó koordinátarendszerből az invariánsba, és vissza.

\subsection{Az első cikk eredményei}

A témakörben írt első cikkben több előkészítő számítás is történt, amely vagy látszólagos elvi problémákat tisztázott, vagy meghatározta a poszt-newtoni közelítésből származó nehézségek megoldását.

Első lépésben kiszámoltuk a relatív sebességvektor komponenseit az invariáns és az együtt-mozgó koordináta-rendszerekben. Azt találtuk, hogy az utóbbiban a vektor ' $z$ ' komponense nem zérus, ha az Euler-szögeket használjuk. Kiderült azonban, hogy a kérdéses vektorkomponens a három Euler-szög közti kényszerfeltételből származik, vagyis

$$
-\dot{\phi} \sin \imath \cos \psi+i \sin \psi=0 .
$$

Ezután részletesen foglalkoztunk a $\imath$ szög megfelelő sorfejtésével. A korábbi munkáinkban az Euler-szögek szögfüggvényeit egyszerü Taylor-sor alakban fejtettük ki, így viszont olyan nem korlátos tagok jelentek meg a korrekciók között, amelyek a hosszú távú (több ezer pályaperiódus) jóslatok esetén hibás eredményeket adtak. 
Ezért általánosabb geometriai megfontolások mentén meghatároztuk a $\imath$ szög szögfüggvényeinek poszt-newtoni rendjét, így eredményeink jobban alkalmazkodnak a komplexebb amplitúdó- és frekvencia-sorfejtés követelményeihez. Az eredmények alapján $\sin \imath$ egy $1,5 \mathrm{PN}$ rendü perturbációként kezelhetö, illetve $\cos l=1$ egészen $3 \mathrm{PN}$ rendig.

Ennek figyelembevételével, illetve az $\Upsilon=\phi+\psi$ szög bevezetésével a meghatározó, és a későbbiekben használt vektormennyiségek alakja különböző koordináta-rendszerekben az alábbi lesz:

$$
\vec{r}_{i n v}=r\left(\begin{array}{c}
\cos \Upsilon \\
\sin \Upsilon \\
\sin \iota \sin \psi
\end{array}\right), \quad \vec{v}_{c o}=\left(\begin{array}{c}
\dot{r} \\
r \dot{\Upsilon} \\
0
\end{array}\right), \quad \vec{L}_{N, c o}=\left(\begin{array}{c}
0 \\
0 \\
\mu r^{2} \dot{\Upsilon}
\end{array}\right), \quad \vec{L}_{N, i n v}=\mu r^{2} \dot{\Upsilon}\left(\begin{array}{c}
\sin \iota \sin \phi \\
-\sin \imath \cos \phi \\
1
\end{array}\right) .
$$

Végül kiszámoltuk az $\vec{N}, \vec{p}, \vec{q}$ vektor-triád vektorainak komponenseit az együtt-mozgó koordinátarendszerben, előkészítve ezzel a gravitációs hullám polarizációs állapotok projektálását.

\subsection{A cikk célkitúzései}

Az első cikk előkészítő számításai után jelen publikációban levezetésre kerülnek a meghatározó szögkombinációkra vonatkozó mozgásegyenletek. Ehhez először konkrét alakban felírásra kerülnek az összetett amplitúdó- és frekvencia-sorfejtés formulái.

Ezek után levezetjük az $\Upsilon$ szög mozgásegyenletét.

Az Euler-szögekre vonatkozó differenciálegyenletek erősen csatoltak, így azok részletes megoldása több nehézséggel is terhelt. Azonban korábbi eredményeinkből jól látható, hogy a gravitációs hullám jelalakok kiszámításához elegendö az $\Upsilon \operatorname{szög~mellett~a~} \sin \imath \sin \phi$ és $\sin \imath \cos \phi$ szögkombinációkat ismernünk. Ezeket a teljes impulzus-momentum vektor segítségével állítjuk elő.

Excentrikus pályák esetén az egyes dinamikai mennyiségek időfüggését nem tudjuk analitikusan meghatározni, szükségünk van a pálya paraméterezésére. Ehhez a valódi anomália paraméterezés általánosítását választjuk, és ennek mentén megadjuk a szögegyenletek megoldásait, illetve tisztázzuk azon módszerek lényegét, amelyekkel meghatározható a paraméter időfüggése.

\section{Az amplitúdó- és frekvencia-sorfejtés alapgondolata}

Ha egy frekvencia-korrekciót is tartalmazó szögmennyiséget a legegyszerübb módon sorba fejtünk, akkor a sorfejtésben fellép egy időben lineárisan növekvő járulék is. Például tekintsük az $\Upsilon$ szöget az

$$
\Upsilon=\left(\omega_{N}+\omega_{1 P N}\right) t+U_{N}(t)+U_{1 P N}(t)
$$

alakban, ahol $\omega=\omega_{N}+\omega_{1 P N}$ állandó szögsebesség, amelyet felbontottunk PN rendek szerint, az $U_{N}(t)$ és $U_{1 P N}(t)$ pedig az indexeknek megfelelö rendủ korlátos függvények. Fejtsük most sorba az $\Upsilon$ szög szinuszát!

$$
\sin \Upsilon=\sin \left(\omega_{N} t+U_{N}(t)\right)+\omega_{1 P N} t \cos \left(\omega_{N} t+U_{N}(t)\right)+U_{1 P N}(t) \cos \left(\omega_{N} t+U_{N}(t)\right)+o(2 P N) .
$$

Jól látható, hogy az 1PN rendủ járulékoknál megjelenik egy időben lineáris szorzóval rendelkező, nem korlátos tag. Lévén $\omega_{1 P N}$ egy 1PN rendü kifejezés, az így fellépő korrekció nem okoz gondot, ha néhány körül-forduláson át követjük csak a szögmennyiség változását. Nekünk azonban sok ezer körül-fordulás esetére is tudnunk kell jóslatot tenni, így a fenti sorfejtés nem megfelelö. 
Ehelyett a sorfejtést úgy végezzük el, hogy külön kezeljük a frekvencia-korrekciókat, és az amplitúdó-korrekcióként kifejthető járulékokat. Így a fenti helyett az alábbi sorfejtést alkalmazzuk:

$$
\sin \Upsilon=\sin \left[\left(\omega_{N}+\omega_{1 P N}\right) t+U_{N}(t)\right]+U_{1 P N}(t) \cos \left[\left(\omega_{N}+\omega_{1 P N}\right) t+U_{N}(t)\right]+o(2 P N),
$$

vagyis leválasztjuk a sorfejtésből a frekvencia-korrekciókat, és a többi (korlátosság tekintetében helyesen kezelt) járulék határozza meg az amplitúdó-korrekciókat. A későbbiekben a spin-pálya korrekciókat is így kezeljük majd.

\section{A szögegyenletek származtatása}

A fenti sorfejtés figyelembe vételével a korábban kiszámolt mozgásegyenleteket újra kell származtatnunk. Azokban ugyanis néhol erősen támaszkodtunk az egyszerủ sorfejtés eredményeire.

\subsection{Spinprecessziós egyenletek}

A testek forgását leíró spin-vektorok dinamikáját korábbi cikkekben részletesen tárgyaltuk [11,12]. Itt a már közölt eredményeket elevenítjük fel, mivel ezekre szükségünk van a többi mozgásegyenlet kiszámításához. A spin-vektorokat egyszerü gömbi polár koordináta-rendszerben írtuk fel úgy, hogy az invariáns koordináta-rendszerben

$$
\vec{S}_{i, i n v}=S_{i}\left(\begin{array}{c}
\cos \beta_{i} \sin \alpha_{i} \\
\sin \beta_{i} \sin \alpha_{i} \\
\cos \alpha_{i}
\end{array}\right)
$$

legyen, és a rá vonatkozó, úgynevezett spinprecessziós egyenlet a spin-pálya kölcsönhatás legalacsonyabb rendjében

$$
\dot{\vec{S}}_{i}=\frac{4+3 \zeta_{i}}{2 r^{3}} \vec{J} \times \vec{S}_{i}
$$

alakú. Ez alapján a mozgásegyenletek

$$
\dot{\alpha}_{i}=0, \quad \dot{\beta}_{i, N}=0, \quad \dot{\beta}_{i, 1 P N}=\frac{\left(4+3 \varsigma_{i}\right) J}{2 r_{N}^{3}} .
$$

\subsection{Az $\Upsilon$ szög egyenlete}

A bevezetőben felírt gyorsulás-kifejezésekből kiszámolható a relatív sebességvektor hossz-négyzete, illetve a szeparációs vektor deriváltjának négyzete. Ezek rendre 


$$
\begin{gathered}
v^{2}=v_{N}^{2}+v_{1 P N}^{2}+v_{S O}^{2}, \quad \text { ahol } \quad v_{N}^{2}=\frac{2 E}{\mu}+\frac{2 m}{r}, \quad v_{S O}^{2}=-\frac{2 \vec{L} \cdot \vec{\sigma}}{\mu r^{3}}, \\
v_{1 P N}^{2}=-3(1-3 \eta)\left(\frac{E}{\mu}\right)^{2}-2(6-7 \eta) \frac{E m}{\mu r}-(10-5 \eta)\left(\frac{m}{r}\right)^{2}+\eta \frac{m L^{2}}{\mu^{2} r^{3}} .
\end{gathered}
$$

és

$$
\begin{aligned}
& \dot{r}^{2}=\dot{r}_{N}^{2}+\dot{r}_{1 P N}^{2}+\dot{r}_{S O}^{2}, \quad \text { ahol } \quad \dot{r}_{N}^{2}=\frac{2 E}{\mu}+\frac{2 m}{r}-\frac{L^{2}}{\mu^{2} r^{2}}, \quad \dot{r}_{S O}^{2}=\frac{2 E \vec{L} \cdot \vec{\sigma}}{m \mu^{2} r^{2}}-\frac{2}{\mu r^{3}}(2 \vec{L} \cdot \vec{S}+\vec{L} \cdot \vec{\sigma}), \\
& \dot{r}_{1 P N}^{2}=-3(1-3 \eta)\left(\frac{E}{\mu}\right)^{2}-2(6-7 \eta) \frac{E m}{\mu r}-(10-5 \eta)\left(\frac{m}{r}\right)^{2}+(2-6 \eta) \frac{E L^{2}}{\mu^{3} r^{2}}+(8-3 \eta) \frac{m L^{2}}{\mu^{2} r^{3}}
\end{aligned}
$$

kifejezések, ahol külön csoportosítottuk azokat a tagokat, amelyek legalább 1PN rendüek, illetve legalacsonyabb, 1,5PN rendben adnak spin-pálya járulékokat. $E$ (a kettős rendszer energiája) és $L$ (az $\vec{L}=\vec{L}_{N}+\vec{L}_{1 P N}+\vec{L}_{S O}$ vektor hossza) a sugárzási $(2,5 \mathrm{PN})$ rendig mozgásállandók.

Fontos kiemelni, hogy a szeparációs vektor hosszán keresztül ezek a kifejezések magasabb rendü járulékokat is tartalmaznak. Amikor megoldjuk az $r$-re vonatkozó egyenletet, a fentiekbe behelyettesítünk, és újra elvégezzük a sorfejtést, kiszürve a magasabb rendủ korrekciókat.

Figyelembe véve, hogy az együtt-mozgó koordinátarendszerben a relatív sebességvektor $\vec{v}_{c o}=(\dot{r}, r \dot{\Upsilon}, 0)$, a keresett szögegyenlet egy egyszerü Pitagorasz-tétel segítségével kiszámolható. Elvégezve a sorfejtést, az alábbi mozgásegyenletre jutunk:

$$
\begin{gathered}
\dot{\Upsilon}=\dot{\Upsilon}_{N}+\dot{\Upsilon}_{1 P N}+\dot{\Upsilon}_{S O}, \quad \text { ahol } \quad \dot{\Upsilon}_{N}=\frac{L}{\mu r^{2}}, \\
\dot{\Upsilon}_{1 P N}=-(1-3 \eta) \frac{E L}{\mu^{2} r^{2}}-(4-2 \eta) \frac{m L}{\mu r^{3}}, \quad \dot{\Upsilon}_{S O}=-\frac{E \vec{L} \cdot \vec{\sigma}}{L m \mu r^{2}}+\frac{2 \vec{L} \cdot \vec{S}}{L r^{3}}
\end{gathered}
$$

\subsection{További szögegyenletek}

Mint a bevezetőben már említettük, a gravitációs hullámokra vonatkozó számolásokból kiderül, hogy a vizsgált rendben a fenti, $\Upsilon$ szög mellett csupán a $\sin \imath \sin \phi$ és $\sin \imath \cos \phi$ szögkombinációk egyenleteire van szükségünk.

Ezek származtatásához írjuk fel a teljes impulzusmomentum vektor komponenseit az invariáns koordinátarendszerben! Ennek során fontos, hogy a szögmennyiségek szögfüggvényeit ne fejtsük sorba, viszont a már ismert mozgáselemeknek csak a megfelelő rendủ tagjait írjuk be a kifejezésekbe. 


$$
\vec{J}_{i n v}=\left(\begin{array}{c}
L \sin \imath \sin \phi+\sum_{i=1}^{2}\left[A_{i} \sin \left(2 \Upsilon-\beta_{i}\right)+B_{i} \cos \left(2 \Upsilon-\beta_{i}\right)+\left(C_{i}+1\right) \cos \beta_{i}\right] S_{i} \sin \alpha_{i} \\
-L \sin \imath \cos \phi+\sum_{i=1}^{2}\left[B_{i} \sin \left(2 \Upsilon-\beta_{i}\right)-A_{i} \cos \left(2 \Upsilon-\beta_{i}\right)+\left(C_{i}+1\right) \sin \beta_{i}\right] S_{i} \sin \alpha_{i} \\
L+\sum_{i=1}^{2}\left(C_{i}+1\right) S_{i} \cos \alpha_{i}
\end{array}\right),
$$

ahol bevezettük az alábbi rövidítő jelöléseket

$$
A_{i}=\frac{\eta \varsigma_{i} \dot{r}_{N} r_{N} \dot{\Upsilon}_{N}}{2}, \quad B_{i}=\frac{\left(2+\varsigma_{i}\right) \mu}{2 r_{N}}-\frac{\eta \varsigma_{i} \dot{r}_{N}^{2}}{4}+\frac{\eta \varsigma_{i} r_{N}^{2} \dot{\Upsilon}_{N}^{2}}{4}, \quad C_{i}=-\frac{\left(2+\varsigma_{i}\right) \mu}{2 r_{N}}+\frac{\eta \varsigma_{i} v_{N}^{2}}{4},
$$

ahol $r_{N}$ jelöli a szeparációs vektor perturbálatlan hosszát.

Mivel a teljes impulzusmomentum vektor az invariáns koordinátarendszerben (annak definíciója mentén) $\vec{J}=(0,0, J)$, a keresett szögkombinációkra vonatkozó egyenletek azonnal elöállnak. Ehhez azonban figyelembe kell vennünk, hogy $\sin \imath$ egy $1,5 \mathrm{PN}$ rendü korrekció, $S_{i} / J$ 0,5PN rendet jelent, illetve az $A-\mathrm{k}, B$-k és $C$-k $1 \mathrm{PN}$ rendü szorzófaktorok. Így az egyenleteknek van egy $0,5 \mathrm{PN}$ és egy $1,5 \mathrm{PN}$ rendben érvényes része. Az előbbit külön megvizsgálva azt kapjuk, hogy

$$
\sum_{i=1}^{2}\left[\left.S_{i}\left(\cos \beta_{i}\right)\right|_{N} \sin \alpha_{i}\right]=0, \quad \sum_{i=1}^{2}\left[\left.S_{i}\left(\sin \beta_{i}\right)\right|_{N} \sin \alpha_{i}\right]=0,
$$

illetve a keresett, 1,5PN rendủ egyenletek az alábbiak:

$$
\begin{aligned}
& \sin \imath \sin \phi=-\frac{1}{L} \sum_{i=1}^{2}\left[A_{i} \sin \left(2 \Upsilon-\beta_{i}\right)+B_{i} \cos \left(2 \Upsilon-\beta_{i}\right)+C_{i} \cos \beta_{i}+\left.\left(\cos \beta_{i}\right)\right|_{1 P N}\right] S_{i} \sin \alpha_{i} \\
& \sin \imath \cos \phi=\frac{1}{L} \sum_{i=1}^{2}\left[B_{i} \sin \left(2 \Upsilon-\beta_{i}\right)-A_{i} \cos \left(2 \Upsilon-\beta_{i}\right)+C_{i} \sin \beta_{i}+\left.\left(\sin \beta_{i}\right)\right|_{1 P N}\right] S_{i} \sin \alpha_{i} .
\end{aligned}
$$

A szeparációs vektor invariáns rendszerben megadott 'z' komponensét az alábbi módon átalakítva

$$
r \sin \imath \sin \psi=r \sin \imath \sin (\Upsilon-\phi)=r(\sin \Upsilon \sin \imath \cos \phi-\cos \Upsilon \sin \imath \sin \phi)
$$

láthatóvá válik, hogy bár a három Euler-szög dinamikáját külön-külön nem határoztuk meg (bár az eddig levezetett egyenletekből származtathatóak lennének), a részletezett egyenletek megoldásával minden információ rendelkezésünkre áll a kettős rendszer mozgását tekintve, 1,5PN rendig.

\section{A mozgásegyenletek megoldásának módszerei}

Mivel a testek excentrikus pályán haladnak, a mozgásegyenletek megoldásához be kell vezetnünk egy alkalmas pálya-paraméterezést, és annak segítségével kell kiintegrálnunk az egyenleteket. 


\subsection{A pálya paraméterezése}

Az excentrikus pályák leírására a valódi anomália paraméterezést választjuk kiindulópontnak, lévén a gravitációs hullámok leírásakor ez adja az áttekinthetőbb és könnyebben értelmezhető megoldásokat. Ezt a fajta paraméterezést kell általánosítani, hogy a poszt-newtoni közelítés magasabb rendjei esetén is érvényes legyen.

Az általánosított valódi anomália paraméterezés definiáló összefüggései az alábbiak:

$$
r(\chi=0)=r_{\min }, \quad r(\chi=\pi)=r_{\max }, \quad \frac{d r}{d(\cos \chi)}=-\gamma r^{2},
$$

ahol $\chi$ a definiált paraméter, $r_{\min }$ és $r_{\max }$ a pálya fordulópontjai (vagyis az $\dot{r}^{2}=0$ egyenlet megoldásai), és az általánosítás részeként a $\gamma$ állandó hordozza a poszt-newtoni rendeket, vagyis $\gamma=\gamma_{N}+\gamma_{1 P N}+\gamma_{S O}$. Ez alapján levezethető a szeparációs vektor hossza a $\chi$ paraméter függvényében:

$$
r(\chi)=r_{N}(\chi)+r_{1 P N}(\chi)+r_{S O}(\chi), \quad \text { ahol } \quad r_{N}(\chi)=\frac{L^{2}}{\mu\left(\mu m+A_{0} \cos \chi\right)},
$$

ahol az $r_{1 P N}(\chi) 1$ PN rendủ korrekciók pontos alakja megtalálható [7] cikkben, az $r_{S O}(\chi)$ 1,5PN rendủ spin-pálya korrekciók pedig a [15] publikációban kerültek levezetésre. Továbbá $A_{0}$ jelöli a Runge-Lenz vektor nagyságának nulladrendủ alakját, amely $A_{0}=\sqrt{\mu^{2} m^{2}+2 E L^{2} / \mu}$.

Ennek ismeretében meghatározható a választott paraméter és az idő közti összefüggés:

$$
\frac{d t}{d \chi}=\frac{\mu r^{2}}{L}+\left.\left(\frac{d t}{d \chi}\right)\right|_{1 P N}+\left.\left(\frac{d t}{d \chi}\right)\right|_{S O},
$$

ahol a korrekciók alakja

$$
\begin{aligned}
& \left.\left(\frac{d t}{d \chi}\right)\right|_{1 P N}=-\frac{\mu r^{2}}{2 L^{3}}\left[(\eta-13) m^{2} \mu^{2}+(3 \eta-1) A_{0}^{2}+(3 \eta-8) m \mu A_{0} \cos \chi\right] \\
& \left.\left(\frac{d t}{d \chi}\right)\right|_{S O}=-\frac{\mu r^{2}}{m L^{5}}\left[(2 \vec{L} \cdot \vec{S}+\vec{L} \cdot \vec{\sigma}) \mu^{2} m\left(3 \mu m+A_{0} \cos \chi\right)-E L^{2} \vec{L} \cdot \vec{\sigma}\right] .
\end{aligned}
$$

\subsection{A szögegyenletek megoldásának módszere}

A számunkra fontos dinamikai mennyiségek egyenletei közül több is algebrai egyenlet. Ilyenek a szeparációs vektor $r$ hossza, a relatív sebesség $v$ nagysága, illetve a $\sin \imath \sin \phi$ és $\sin \imath \cos \phi$ szögkombinációk. Ezekbe elegendő behelyettesíteni a kiintegrált mennyiségeket a $\chi$ paraméter függvényében, majd az így kapott összefüggésekbe helyettesítjük be a paraméter időfüggésére $\chi(t)$ vonatkozó eredményeket (ezeket numerikus módszerekkel tudjuk elő́llítani). 
Az $r(\chi)$ függvényt a fentiekben már megadtuk, a spin-vektorok komponenseit meghatározó $\beta_{i}(\chi)$ szögek kiintegrálása pedig korábbi munkáinkban megtalálható $[6,11,12]$ :

$$
\beta_{i}=\beta_{i 0}+\frac{J \mu^{3} m\left(4+3 \varsigma_{i}\right)}{2 L^{3}} \chi-\frac{J \mu^{2} A_{0}\left(4+3 \varsigma_{i}\right)}{2 L^{3}} \sin \chi,
$$

ahol $\beta_{i 0}$ jelöli az integrálási konstansokat.

Azonban az $\Upsilon(\chi)$ kifejezést még ki kell számolnunk. A szögre vonatkozó egyenlet a valódi anomália paraméter függvényében a mozgásegyenlet

$$
\frac{d \Upsilon}{d \chi}=\dot{\Upsilon} \frac{d t}{d \chi}=1+\frac{m \mu}{2 L^{2}}\left[6 m \mu+\eta A_{0} \cos \chi\right]-\frac{\mu^{2}}{L^{4}}\left[m \mu \vec{L} \cdot(4 \vec{S}+3 \vec{\sigma})+A_{0} \vec{L} \cdot \vec{\sigma} \cos \chi\right]
$$

lesz, és ennek integrálásával megkapjuk az alábbi eredményt

$$
\Upsilon=\Upsilon_{0}+\chi+\frac{3 m^{2} \mu^{2}}{L^{2}} \chi+\frac{\eta A_{0} m \mu}{2 L^{2}} \sin \chi-\frac{\mu^{3} m \vec{L} \cdot(4 \vec{S}+3 \vec{\sigma})}{L^{4}} \chi-\frac{A_{0} \mu^{2} \vec{L} \cdot \vec{\sigma}}{L^{4}} \sin \chi .
$$

\section{A frekvencia- és amplitúdó-sorfejtés módszere}

Az eredmények ismeretében ismét rátekintünk a sorfejtési módszer konkrétumaira. Látható, hogy a $\beta_{i}(\chi)$ és $\Upsilon(\chi)$ szögek nagyon hasonló szerkezetüek, csak az adott rendhez tartozó konstans együtthatókban különböznek. Az alábbi megfontolások így csak az $\Upsilon(\chi)$ szög esetében kerülnek kifejtésre.

Látható, hogy az $\Upsilon(\chi)$ szög tartalmaz a valódi anomália paraméterben lineáris és korlátos posztnewtoni korrekciókat is. Vezessük be a szög kifejezését az alábbi, egyszerü alakban:

$$
\Upsilon=\Upsilon_{0}+\chi+U_{P} \chi+V_{P} \sin \chi,
$$

ahol $U_{P}$ és $V_{P}$ konstansok, és tartalmazzák az $1 \mathrm{PN}$ rendủ és spin-pálya korrekciók együtthatóit is (lévén a kettő nem „keveredik”). Ekkor példaként a szög szinuszát az alábbi alakban fejtjük sorba:

$$
\sin \Upsilon=\sin \left[\Upsilon_{0}+\left(1+U_{P}\right) \chi\right]+V_{P} \sin \chi \cos \left[\Upsilon_{0}+\left(1+U_{P}\right) \chi\right]+o(2 P N) .
$$

Azonban a helyzet ennél összetettebb, mivel excentrikus pálya esetén a valódi anomália paraméter időfüggése is hasonló tagokat tartalmaz. Belátható [7], hogy a vizsgált poszt-newtoni rendekben a $\chi$ paraméter időfüggése felírható, mint

$$
\chi(t)=\left(\Omega_{N}+\Omega_{P}\right) t+g_{N}(t)+g_{P}(t),
$$

ahol $\Omega_{N}$ és $\Omega_{P}$ időben állandó frekvenciák, illetve $g_{N}(t)$ és $g_{P}(t)$ korlátos függvények. Itt ismét $\mathrm{P}$ index-szel jelöltük az 1 PN és spin-pálya korrekciók összegét. Fontos kiemelni, hogy a fenti mennyiségeket numerikus integrálással tudjuk konkrét esetben meghatározni.

Ennek behelyettesítésével, és elvégezve a frekvencia és amplitúdó sorfejtést 


$$
\begin{gathered}
\Upsilon=\Upsilon_{0}+\left(\Omega_{N}+\Omega_{P}+\Omega_{N} U_{P}\right) t+g_{N}(t)+ \\
+A_{P} g_{N}(t)+g_{P}(t)+V_{P} \sin \left[\left(\Omega_{N}+\Omega_{P}\right) t+g_{N}(t)\right]+o(2 P N)
\end{gathered}
$$

eredményt kaptuk, ahol az alsó sorban szerepelnek az amplitúdó-korrekciók. Hasonló összefüggést kaphatunk a $\beta_{i}$ szögekre is. Ezen kifejezések kombinációinak szinuszai és koszinuszai (és ezek felharmonikusai) alkotják a detektálható gravitációs hullámforma kifejezéseit. Követve a kettős sorfejtés szabályait - vagyis csak a korlátos perturbációk szerint fejtjük ki a szögfüggvényeket, a lineáris tagokat frekvencia-perturbációként kezeljük - megkapjuk a hullámformákra vonatkozó analitikus kifejezéseket. Ezekbe helyettesítjük be a numerikus számítások eredményeit.

\section{6. Összefoglaló}

Jelen cikkben kiszámoltuk a releváns szögmennyiségekre vonatkozó mozgásegyenleteket.

A valódi anomália paraméterezés alkalmazásával analitikusan sikerült az integrálandó mozgásegyenleteket megoldanunk, a többi algebrai egyenletként állt elö, azok egyszerü behelyettesítéssel adják meg az analitikus kapcsolatot a többi dinamikai változóval.

Megadtuk a vezérfonalat a paraméter időfüggésének kiintegrálásához. Ezt analitikusan nem tudjuk megoldani, numerikus módszerek alkalmazása szükséges a konkrét esetek kiértékeléséhez.

Továbbá részleteztük a komplex amplitúdó- és frekvencia sorfejtést, amellyel az egyszerü Taylorsorba fejtés során fellépő nem korlátos korrekciókat kezelhetjük helyesen.

Mindezeket összefoglalva a két cikkben tisztáztuk a kettős rendszer mozgása leírásának kereteit és lépéseit a poszt-newtoni sorfejtést alkalmazva. Mivel excentrikus pályák esetén a végeredmény az utolsó lépésben csak numerikus eljárásokkal állítható elö, a célunk az volt, hogy olyan módszert adjunk, amelynek segítségével bárki egy konkrét kettős rendszer esetén kiszámolhatja a mozgást leíró mennyiségeket. Számunkra ez azért is fontos, mert ez adja az alapját a kettős rendszer által kibocsátott, és a detektorokban érzékelhető jelalakok kiszámolásához.

A módszer röviden összefoglalva az alábbi menetrendet követi.

Első lépésben szükséges a paraméter időfüggésének numerikus meghatározása. Ezt úgy kell tudni megoldani, hogy különválaszthatóak legyenek a frekvencia-korrekciók és a korlátos függvényt követő amplitúdó-korrekciók.

Ezeket lehet behelyettesíteni az $\Upsilon$ és $\beta$ szögek kifejezéseibe, majd - helyesen kezelve a sorfejtést kiszámolhatjuk a $\sin \imath \sin \phi$ és $\sin \imath \cos \phi$ kombinációkat.

Ezek segítségével adhatóak meg a releváns vektormennyiségek (szeparációs vektor, relatív sebességvektor, spinvektorok, $\vec{N}, \vec{p}, \vec{q}$ vektor-triád) komponensei.

A kutatásaink következő lépése a fenti módszer követésével a gravitációs hullám jelalakok kiszámítása több, különböző lehetséges hullámforrás esetén. 


\section{Irodalom}

[1] Abbott, B. P., et al.: Observation of Gravitational Waves from a Binary Black Hole Merger, Phys. Rev. Lett. 116, 061102 (2016) https://doi.org/10.1103/PhysRevLett.116.061102

[2] Abbott, B. P., et al.: GW151226: Observation of Gravitational Waves from a 22-Solar-Mass Binary Black Hole Coalescence, Phys. Rev. Lett. 116, 241103 (2016) https://doi.org/10.1103/PhysRevLett.116.241103

[3] Abbott, B. P., et al.: GW170104: Observation of a 50-Solar-Mass Binary Black Hole Coalescence at Redshift 0.2, Phys. Rev. Lett. 118, 221101 (2017) https://doi.org/10.1103/PhysRevLett.118.221101

[4] Abbott, B. P., et al.: GW170814: A Three-Detector Observation of Gravitational Waves from a Binary Black Hole Coalescence, Phys. Rev. Lett. 119, 141101 (2017) https://doi.org/10.1103/PhysRevLett.119.141101

[5] Abbott, B. P., et al.: GW170817: Observation of Gravitational Waves from a Binary Neutron Star Inspiral, Phys. Rev. Lett. 119, $161101 \quad$ (2017) https://doi.org/10.1103/PhysRevLett.119.161101

[6] Majár, J., Vasúth, M.: Gravitational waveforms for spinning compact binaries, Phys. Rev. D77, 104005 (2008) https://doi.org/10.1103/PhysRevD.77.104005

[7] Majár, J., Forgács, P., Vasúth, M.: Gravitational waves from binaries on unbound orbits, Phys. Rev. D82, 064041 (2010) https://doi.org/10.1103/PhysRevD.82.064041

[8] Blanchet, L.: On the multipole expansion of the gravitational field, Classical Quantum Gravity 15 1971-1999 (1998) https://doi.org/10.1088/0264-9381/15/7/013

[9] Kidder, L. E.: Coalescing binary systems of compact objects to (post $)^{5 / 2}$-Newtonian order. V. Spin effects, Phys. Rev. D52, 821 (1995) https://doi.org/10.1103/PhysRevD.52.821

[10] Mikóczi, B.: Spin supplementary conditions for spinning compact binaries, Phys. Rev. D95, 064023 (2017) https://doi.org/10.1103/PhysRevD.95.064023

[11] Majár, J.: Spin-spin interaction in the spin-precession equations, Phys. Rev. D80, 104028 (2009) https://doi.org/10.1103/PhysRevD.80.104028

[12] Majár, J., Mikóczi, B.: Second order spin effects in the spin precession of compact binaries, Phys. Rev. D86, 064028 (2012) https://doi.org/10.1103/PhysRevD.86.064028

[13] Keresztes, Z., Mikóczi, B., Gergely, L. Á.: The Kepler equation for inspiralling compact binaries, Phys. Rev. D72, 104022 (2005) https://doi.org/10.1103/PhysRevD.72.104022

[14] Keresztes, Z., Mikóczi, B., Gergely, L. Á., Vasúth, M.: Secular momentum transport by gravitational waves from spinning compact binaries, J. Phys. Conf. Ser. 228, 012053 (2010) https://doi.org/10.1088/1742-6596/228/1/012053

[15] Gergely, L. Á., Perjés, Z. I., Vasúth, M.: Spin effects in gravitational radiation back reaction. III. Compact binaries with two spinning components, Phys. Rev. D58, 124001 (1998) https://doi.org/10.1103/PhysRevD.58.124001 